J. Clin. Chem. Clin. Biochem.

Vol. 18,1980 , pp. $563-566$

\title{
Isolation of the Two Monoferric Human Transferrins by Preparative Isoelectric Focussing
}

\author{
By H. G. van Eijk, W. L. van Noort, M. J. Kroos and C. van der Heul \\ Departments of Chemical Pathology and Hematology, Medical Faculty, Erasmus University, Rotterdam, \\ The Netherlands
}

(Received January 30, 1980)

Summary: 1. Human transferrin was labelled with $\mathrm{Fe}$ (III) in nitrilo triacetate buffer at one of its two metal binding sites by variation of the $\mathrm{pH}$. The A-site was preferentially labelled at $\mathrm{pH} 7.2$, the $\mathrm{B}$-site at $\mathrm{pH} 9.2$.

2. The monoferric transferrin preparations were subjected to preparative isoelectric focussing, isolated from the granulated gels, and checked for homogeneity and purity on an analytical scale by isoelectric focussing.

3. The technique for obtaining stable monoferric transferrin $(\mathrm{Fe})(\mathrm{A})$ and transferrin $(\mathrm{Fe})(\mathrm{B})$ preparations is described in detail.

Isolierung von Transferrin $(\mathrm{Fe})(\mathrm{A})$ und Transferrin $(\mathrm{Fe})(\mathrm{B})$ des Menschen durch präparative isoelektrische Fokussierung

Zusammenfassung: 1. Transferrin vom Menschen wurde mit Fe(III) in Nitrilotriacetatpuffer durch Variation des $\mathrm{pH}$ an einer seiner zwei Metallbindungsstellen markiert. Bindungsstelle A wird vorzugsweise bei $\mathrm{pH} 7,2$, Bindungsstelle $\mathrm{B}$ bei pH 9,2 markiert.

2. Die jeweils ein Eisen enthaltenden Transferrin-Präparationen wurden der präparativen isoelektrischen Fokussierung unterworfen, aus dem granulierten Gel isoliert und durch analytische isoelektrische Fokussierung auf ihre Homogenität und Reinheit geprüft.

3. Die Technik für die Darstellung stabiler, ein Eisen enthaltender Transferrine wird im Detail beschrieben.

\section{Introduction}

Transferrin is a $\beta$-globulin responsible for carrying iron in the plasma. This protein has a $M_{\mathrm{r}}$ of 81000 , consists of a single polypeptide chain and has two metal binding sites. There is still doubt whether the two binding sites, called the B-site and A-site, located in the $\mathrm{N}$ terminal domain, $\mathrm{C}$ terminal domain (1), respectively fulfill different physiological roles $(2,3)$. In a previous paper we showed that these two binding sites have different affinities for $\mathrm{Fe}(\mathrm{III})$ at various $\mathrm{pH}$ values, and that the isoelectric points of the two monoferric transferrins differ by $0.1 \mathrm{pH}$ unit (4). This was determined by the elegant flat bed isoelectric focussing technique in polyacrylamide gel.

In this paper we present a preparative method, a flat-bed isoelectric focussing technique in granulated gels, which enables us to separate and isolate each monoferric transferrins on a $10 \mathrm{mg}$ level. By incubating individual trans- ferrins with ery throid and parenchymal cells, it is possible to investigate the question (suggested by Fletcher \& Huehns over a decade ago) as to whether these two binding sites of transferrin have distinctive roles in iron transport and metabolism (5).

\section{Materials and Methods}

Human transferrin was obtained from Kabi (Sweden) and used without further purification.

Apotransferrin was prepared as described earlier (6) by dialysis against EDTA. A nitrilo triacetate (NTA) pH-buffer was made by titration of $\mathrm{Na}_{3}$ NTA with NTA (Sigma) until the desired pH was obtained.

Chemicals were of analytical reagent grade.

Ampholines pH 5-7 and granulated gel (Ultrodex) were obtained from LKB (Sweden). ${ }^{59} \mathrm{Fe}$ (III) citrate was obtained from Radiochemical Centre, Amersham, Bucks, United Kingdom and was diluted about five fold with freshly prepared ${ }^{56} \mathrm{Fe}$ (III) citrate $(0 ; 6 \mathrm{~g} / 1)$. To this solution $\mathrm{NaHCO}_{3}$ was added in a molar ratio $\mathrm{Fe} / \mathrm{HCO}_{3}=1 / 50$. 


\section{Preparation of monoferric transferrins $A$ and $B$}

To a solution of human apotransferrin (ca. $60 \mathrm{~g} / \mathrm{l}) 10 \mathrm{vol} \%$ $1 \mathrm{~mol} / 1 \mathrm{NTA}$ buffer was added of either $\mathrm{pH}=7.2$ (transferrin $(\mathrm{Fe})(\mathrm{A}))$ or 9.2 (transferrin(Fe)(B)).

Then the apotransferrin solutions were brought to a $0.60 \mathrm{Fe}$ saturation with the mixed ${ }^{56} \mathrm{Fe} /{ }^{59} \mathrm{Fe}$ citrate solution (about $1 \mathrm{mmol} / 1 \mathrm{Fe}$ ).

The Fe-transferrin solutions were kept overnight at room temperature, then dialy sed for 24 hours at $4^{\circ} \mathrm{C}$ against 1 litre $0.1 \mathrm{~mol} / 1$ Tris $\mathrm{pH}=7$ (A), or $\mathrm{pH}=9$ (B). After dialysis the Fe-transferrin solutions were used for preparative isoelectric focussing which was carried out according to the Application Note 198 (LKB) with the LKB 2117 Multiphor, but with a few minor adaptations.

Instead of Sephadex G75, a new granulated gel, Ultrodex, was used. Four (4) grams of the freeze dried powder was suspended in $100 \mathrm{ml}$ of a $20 \mathrm{~g} / \mathrm{l}$ ampholine $\mathrm{pH} \mathrm{5-7}$ solution. The focussing was carried out over the broad-short region instead of the narrow long region. Between the gel bearing glass plate and the cooling glass plate two sheets of wetted filter paper were placed to make it easier to distinguish the transferrin-Fe bands after focussing.

Before applying the sample, the gel was prerun for 60-90 minutes. Instead of the low power and time-consuming adjustment given by LKB, we started the prerun with $500 \mathrm{~V}$ and $50 \mathrm{~mA}$, and these values automatically changed during focussing to $900 \mathrm{~V}$ and $35 \mathrm{~mA}$. Maxima of $1200 \mathrm{~V}, 30 \mathrm{~W}$ and $50 \mathrm{~mA}$ were adjusted. A fast, high power focussing is necessary because the relative low stability of transferrin( $\mathrm{Fe}$ (B). Instead of mixing the sample with the gel, it was absorbed into a dry electrode strip (ca. $70 \mu \mathrm{l} / \mathrm{cm}$ strip), then the strip was carefully pressed into the gel parallel to the electrode strips at a distance of $1 \mathrm{~cm}$ from the cathode.

The focussing was performed in 100-140 minutes until sharp bands had been formed (visible from their pink color).

Next with a glass spatula the protein containing gel (zones) were scooped into special elution columns (LKB, 2117-502). Transferrin $(\mathrm{Fe})(\mathrm{A})$ and transferrin $(\mathrm{Fe})(\mathrm{B})$ were eluted with $0.5 \mathrm{~mol} / 1$ Tris pH 7 or 8 , respectively. The eluates were dialyzed overnight at $4{ }^{\circ} \mathrm{C}$ against 11 each of a $0.02 \mathrm{~mol} / 1$ Tris buffer $\mathrm{pH}=7$ or 8 , respectively. Elution and dialysis buffer were made $\mathrm{Fe}$-free by passing the solution through a small column of Chelex 100 (Biorad).

Finally the fractions were tested for homogeneity on a polyacrylamide gel on an analy tical scale (4) and used for incubation studies with rat reticulocy tes and bone marrow cells, as well as with human bone marrow cells. These experiments are described elsewhere (5).

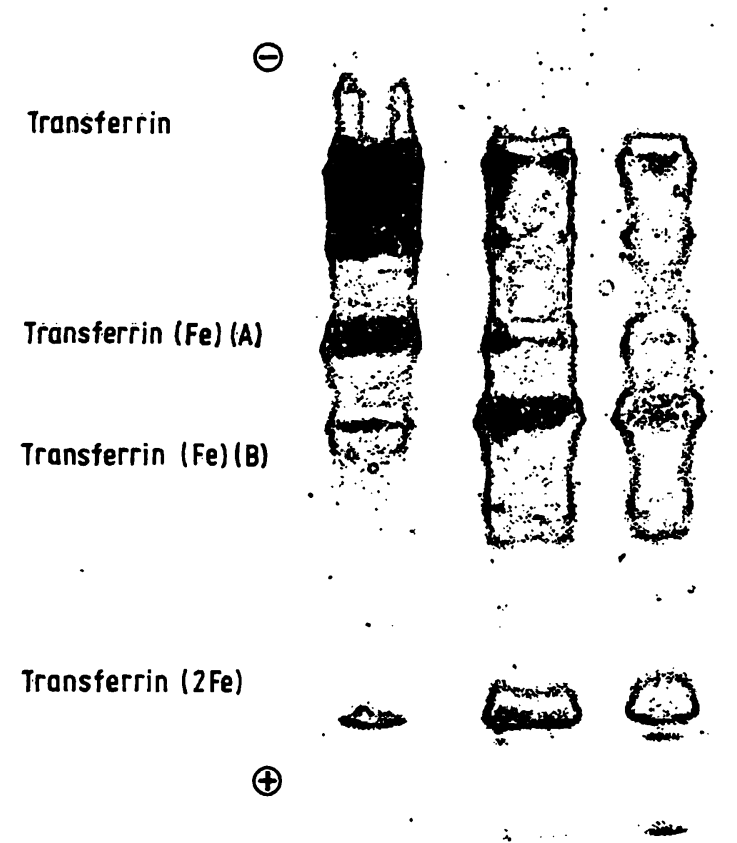

Fig. 1. Preparative isoelectric focussing.

Transferrin( $\mathrm{Fe}$ (A) (Fe N-terminal left) and transferrin$(\mathrm{Fe})(\mathrm{B})(\mathrm{Fe} \mathrm{C}$-terminal right) as well as transferrin $(2 \mathrm{Fe})$ are visible.

of transferrin( $\mathrm{Fe})(\mathrm{B})$ and some transferrin $(2 \mathrm{Fe})$ was obtained in the focussing (left); if the sample was not dialysed (i.e. the chelators were not removed) most of the transferrin( $\mathrm{Fe})(\mathrm{B})$ was converted to transferrin(Fe)(A) during the focussing (fig. 3 right). Surprisingly, this conversion was not observed on the analytical gel (fig. 1 right). The transferrin(Fe)(A) and transferrin$(\mathrm{Fe})(\mathrm{B})$ preparations obtained from the preparative gels were focussed again on an analytical scale. This result is shown in figure 4 .

\section{Results}

In figure 1 a typical diagram of the separation of specifically labelled monoferric transferrin( $\mathrm{Fe})(\mathrm{A})$ and transferrin $(\mathrm{Fe})(\mathrm{B})$ is shown. On the left is a labelling at $\mathrm{pH} 7.2$, mainly A-site, and in the middle a labelling at $\mathrm{pH} 9.2$, mainly the B-site. The labelling occurred in a NTA buffer, the separation of $70 \mu \mathrm{g}$ samples on polyacrylamide gels with isoelectric focussing as has been described earlier (4). In figures 2 and 3 are shown the separation of about $7 \mathrm{mg}$ samples in granulated gels (Ultrodex). The gels are stained for iron, so apotransferrin is not visible. On the left in figure 2 is shown transferrin( $\mathrm{Fe})(\mathrm{A})$, and transferrin $(\mathrm{Fe})(\mathrm{B})$ is on the right. In figure 3 is shown the result of dialysing the sample after labelling the transferrin with $\mathrm{Fe}$ (III). If the sample of transferrin( $\mathrm{Fe})(\mathrm{B})$ was dialysed in order to remove chelators a sharp band

\section{Discussion}

With the method, described here in detail, it appears possible to separate and isolate monoferric human transferrins A and B. The yield is at least $20 \%$ under favourable conditions.

We wish to draw attention on the conditions necessary for optimal preparative focussing.

1. To obtain pure transferrin( $\mathrm{Fe})(\mathrm{B})$ it is absolutely necessary to remove NTA and citrate by dialysis or gel filtration before transferrin( $\mathrm{Fe})(\mathrm{B})$ solutions are subjected to preparative focussing. If this step is - omitted a considerable amount of transferrin(Fe)(B) is converted into transferrin $(\mathrm{Fe})(\mathrm{A})$ during focussing and transferrin $(\mathrm{Fe})(\mathrm{B})$ preparations are than contaminated with transferrin( $\mathrm{Fe})(\mathrm{A})$. 


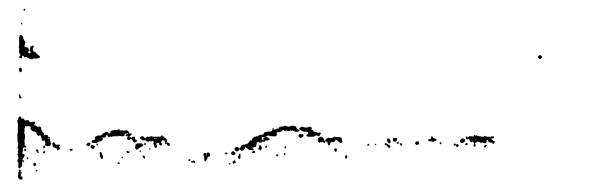

\author{
$\Theta$ \\ Transferrin \\ Transferrin (Fe)(A) \\ Transferrin (Fe)(B)
}

Transferrin ( $2 \mathrm{Fe})$

$\oplus$

Fig. 2. The same solutions as in fig. 1, but on analytical gels.

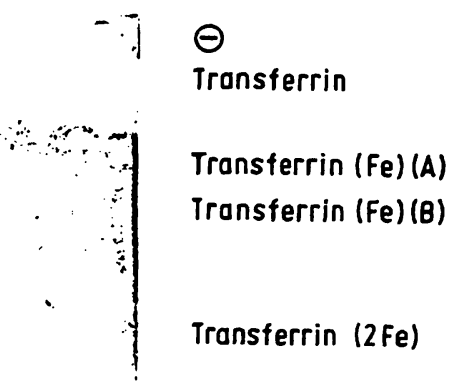

$\oplus$

Fig. 3. Isoelectric focussing of (a) solutions which contain chelators, not removed before the focussing technique (left) and (b) solutions from which chelators were removed before the focussing (right), in this case only transferrin $(\mathrm{Fe})(\mathrm{B})$ is seen and not transferrin(Fe)(A).

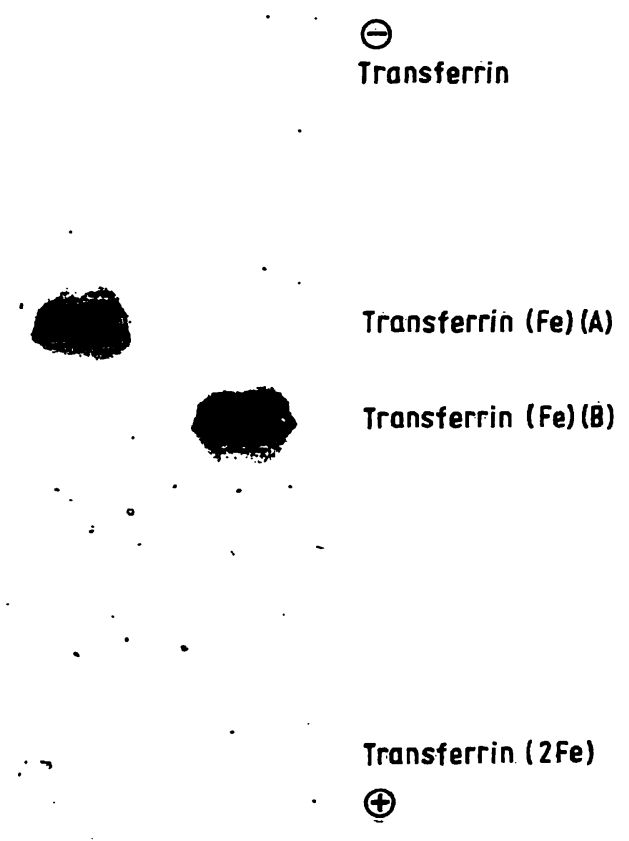

Fig. 4. Ișoelectric focusșing on an analytical scale of samples prepared by the preparative technique.

The pure transferrin(Fe)(A)(left) and transferrin(Fe)(B)(right) obtained by preparative isoelectric focussing, dialysed as described and ready for incubation experiment.
Moreover the yield is diminished. Removing chelators from transferrin $(\mathrm{Fe})(\mathrm{A})$ solutions before focussing resulted in sharper migration.

2. The optimal and most reproducible ratio of transferrin( $\mathrm{Fe})(\mathrm{A})$ to transferrin( $\mathrm{Fe})(\mathrm{B})$ was found when the labelling of apotransferrin with $\mathrm{Fe}$ was carried out in a NTA buffer, with an excess of $\mathrm{HCO}_{3}{ }^{-}$, so that $\mathrm{HCO}_{3}{ }^{-}$and not NTA is bound as an anion (7).

3. A solution of high concentration, at least $30 \mathrm{~g} / 1$, is necessary in order to work with sample volumes of $1.5-2 \mathrm{ml}$ and to obtain a reasonable amount of protein.

4. To prove that the ampholine had no harmful effect on the nature of the protein we carried out several incubation experiments with reticulocytes and transferrin-solutions, treated or non-treated with ampholine. No differences were observed in iron uptake (5). 


\section{References}

1. Evans, R. W. \& Williams, J. (1978), Biochem. J. 173 , 543-552.

2. Fletcher, J. \& Huehns, E. R. (1968), Nature 218, 1211-1214.

3. Fletcher, J. \& Huehns, E. R. (1967), Nature 215, 584-586.

4. Van Eijk, H. G., Van Noort, W. L., Kroos, M. J. \& Van der Heul, C. (1978), J. Clin. Chem. Clin. Biochem. 16, 557-560.
5. Vañ der Heul, C., Kroos, M. J., Vañ Noort, W. L. \& Van Eijk, H. G., Clin. Sciènce, accepted for publication.

6. Verhoef, N. J. \& Van Eijk; H. G. (1975), Clin. Sci. Mol. Med. $48,335-340$

7. Schlabach, M. R. \& Bates, G. W. (1975), J. Biol. Chem. 250, 2182-2188.

Prof. Dr. H. G: van Eijk

Dept. of Chemical Pathology

Erasmus University Rotterdam

Postbus 1738

Rotterdam 